\title{
Safe and Scalable Continuous Flow Azidophenylselenylation of Galactal to Prepare Galactosamine Building Blocks
}

\author{
Mónica Guberman, ${ }^{\dagger \neq}$ Bartholomäus Pieber, ${ }^{\dagger}$ and Peter H. Seeberger*, ${ }^{*}, \ddagger$ (†) \\ ${ }^{\dagger}$ Department of Biomolecular Systems, Max Planck Institute of Colloids and Interfaces, Am Mühlenberg 1, 14476 Potsdam, \\ Germany \\ ${ }^{\ddagger}$ Department of Chemistry and Biochemistry, Freie Universität Berlin, Arnimalle 22, 14195 Berlin, Germany
}

Supporting Information

\begin{abstract}
Differentially protected galactosamine building blocks are key components for the synthesis of human and bacterial oligosaccharides. The azidophenylselenylation of 3,4,6-tri-O-acetyl-D-galactal provides straightforward access to the corresponding 2-nitrogenated glycoside. Poor reproducibility and the use of azides that lead to the formation of potentially explosive and toxic species limit the scalability of this reaction and render it a bottleneck for carbohydrate synthesis. Here, we present a method for the safe, efficient, and reliable azidophenylselenylation of 3,4,6-tri-O-acetyl-D-galactal at room temperature, using continuous flow chemistry. Careful analysis of the transformation resulted in reaction conditions that produce minimal side products while the reaction time was reduced drastically when compared to batch reactions. The flow setup is readily scalable to process $5 \mathrm{mmol}$ of galactal in $3 \mathrm{~h}$, producing $1.2 \mathrm{mmol} / \mathrm{h}$ of product.
\end{abstract}

KEYWORDS: azides, continuous flow, galactosamine, azidophenylselenylation, carbohydrate chemistry

\section{INTRODUCTION}

Galactosamine (GalN) is ubiquitous in living organisms, and the $\mathrm{N}$-acetyl galactosamine (GalNAc) is one of the nine monosaccharide building blocks that give rise to all mammalian glycans. ${ }^{1}$ Many bacteria present GalNAc-containing glycans on their cell surface. ${ }^{2}$ Synthetic oligosaccharides are valuable tools to investigate glycan function and are used as diagnostics, ${ }^{3}$ vaccines, ${ }^{4}$ and drugs. ${ }^{5}$ Suitably protected monosaccharide building blocks are needed to assemble the desired oligosaccharides. ${ }^{6}$ While commercially available glucosamine (GlcN) can be used as starting material for $N$-acetyl glucosamine (GlcNAc) building blocks, the high price of galactosamine hampers large scale synthetic applications. Therefore, several strategies to prepare 2-nitrogenated glycoside analogues from inexpensive starting materials have been developed. $^{7-13}$ Azidophenylselenylation (APS) is a commonly used nitrogen transfer reaction to prepare galactosamine building blocks from the corresponding galactals. ${ }^{14-16}$ APS introduces two functional groups in a single step, the resulting selenoglycosides are compatible with a wide range of protecting group manipulations and can be activated to prepare 1,2-cis and 1,2-trans glycosides (Scheme 1).
The highly exothermic APS reaction is commonly carried out using $\mathrm{TMSN}_{3}$ as an azido source, ${ }^{14}$ due to lower explosion hazard as well as higher solubility in organic solvents when compared to $\mathrm{NaN}_{3} \cdot{ }^{12,16,17}$ While relatively good yields were reported, ${ }^{14}$ this transformation is difficult to reproduce reliably. Yields of 23 experiments carried out in our department over the past 10 years range from $10 \%$ to $65 \%$ with an average yield of $35 \%$ (see Supporting Information for details). The poor selectivity and irreproducibility are likely a consequence of deficiencies in mixing and temperature control during batch reactions. The potentially explosive and toxic nature of azido compounds-in particular the possibility of hydrazoic acid formation-causes severe safety risks and limits reaction scaleup in conventional batch approaches. ${ }^{18}$ We hoped to address these issues by performing the APS reaction under continuous flow conditions and to benefit from reproducible and efficient mixing and heat transfer. ${ }^{19-21}$ The concentration of potentially hazardous side products generated at any time is minimal during the flow regime and facilitates reaction scale-up. ${ }^{19-21}$

\section{RESULTS AND DISCUSSION}

Common APS reaction protocols in batch ${ }^{14}$ call for the addition of $\mathrm{TMSN}_{3}$ to a solution of 3,4,6-tri-O-acetyl-D-galactal (1) and $\mathrm{Ph}_{2} \mathrm{Se}_{2}$ in anhydrous $\mathrm{DCM}$ at $-30{ }^{\circ} \mathrm{C}$. After the addition of bisacetoxy iodobenzene (BAIB), the reaction mixture is warmed to $-10{ }^{\circ} \mathrm{C}$. Reaction times are variable and typically range from 4 to $16 \mathrm{~h} .{ }^{14,22}$ Low temperatures during mixing minimize explosion hazards and avoid high concentrations of azido radicals due to the fast reaction between $\mathrm{TMSN}_{3}$ and $\mathrm{BAIB}^{23}$ that would lead to unproductive formation of $\mathrm{N}_{2}$ and undesired bisazido side products.

Initial experiments showed that mixing 3,4,6-tri-O-acetyl-Dgalactal (1), $\mathrm{Ph}_{2} \mathrm{Se}_{2}$, and $\mathrm{TMSN}_{3}$ did not result in any reaction over a $2 \mathrm{~h}$ period, and the reaction only started after BAIB addition (see Supporting Information). Consequently, a flow setup consisting of two reagent feeds (Feed A: 3,4,6-tri-Oacetyl-D-galactal (1), $\mathrm{Ph}_{2} \mathrm{Se}_{2}$ and $\mathrm{TMSN}_{3}$ in anhydrous DCM; Feed B: BAIB in anhydrous DCM) was assembled (Figure 1). The liquid streams were pumped using HPLC pumps ${ }^{24}$ and mixed in a $\mathrm{T}$-piece before entering a residence time unit that was immersed in a thermostatic bath. Sample loops were connected to the liquid stream via six-way valves to introduce the reagent solution to the flow stream. The reaction mixture

Received: October 22, 2019

Published: December 4, 2019 
Scheme 1. Galactosamine Building Blocks Are Obtained via Nitrogen Transfer to Glycals ${ }^{a}$

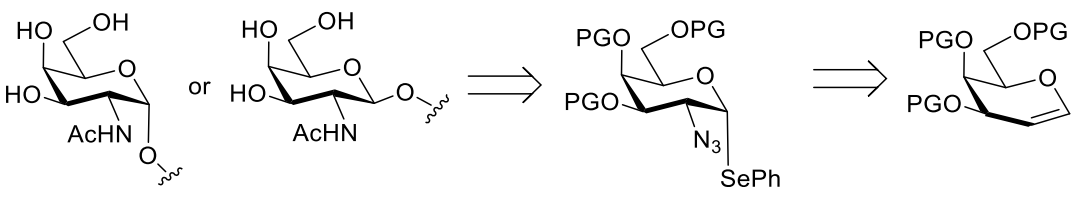

${ }^{a}$ PG: Protecting group.
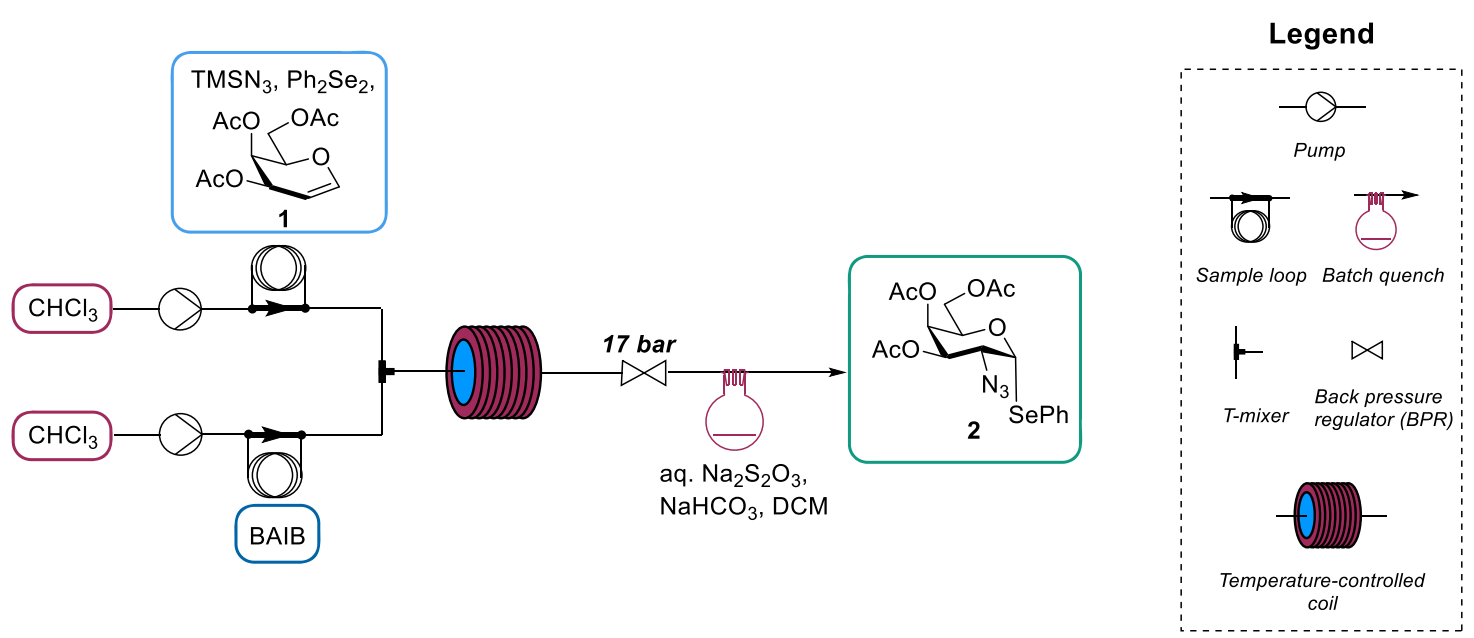

Figure 1. Continuous flow setup for the azidophenylselenylation of 3,4,6-tri-O-acetyl-D-galactal (1).

finally passed a backpressure regulating unit (17 bar) and was quenched offline. Pressurizing the system was essential to avoid the formation of a biphasic gas/liquid flow pattern resulting from the formation of $\mathrm{N}_{2}$ to guarantee reproducible flow processes. To ensure immediate quenching, the reaction mixture was collected in a vigorously stirred mixture of dichloromethane and an aqueous solution containing $\mathrm{Na}_{2} \mathrm{~S}_{2} \mathrm{O}_{3}$ (to reduce unreacted $\mathrm{BAIB}$ ) and $\mathrm{NaHCO}_{3}$ to prevent the formation of hydrazoic acid (for details the see Supporting Information).

In order to optimize the reaction conditions, the crude reaction mixtures were carefully analyzed by ${ }^{1} \mathrm{H}$ NMR. Preliminary experiments showed the presence of the desired azidophenylselenylation product 2 and up to six different side products (3-8, Figure 2), including the talo stereoisomer 3, the regioisomers 4 and 5, the bisazido monosaccharides 6 and 7, and 1-O-acetyl glycoside 8 (Figure 2). Remarkable selectivity toward $\alpha$-glycosides $(\mathbf{2}-\mathbf{6}, \mathbf{8})$ was noted, with the $\beta$-bisazido species (7) only observed occasionally. A mechanism where an initial ligand exchange on the BAIB generates the azido radicals was previously proposed. ${ }^{23}$ Subsequent addition of the azido radical to the glycal double bond to form an anomeric (pyranos-1-yl) radical accounts for the regioselectivity toward 2 -azido products $(2,3,6-8)$. The pseudoaxial disposition of the C4-substituent hindering the $\beta$ face accounts for the stereoselectivity for equatorial (galacto products 2, 5-8) over axial (talo products 3-4) substituents at $\mathrm{C} 2{ }^{25} \alpha$-Selectivity is commonly observed in galactal reactions, and it is attributed to the anomeric effect and the pseudoaxial disposition of the C4-OAc. ${ }^{11}$ BAIB is the source for the acetoxy moiety in acetyl glycoside 8 . Side products bearing acetoxy groups were observed in the presence of BAIB in the azidophenylselenylation of olefins, where acetoxyphenylsenelyl compounds were identified. ${ }^{26}$ Formation of both 2-phenylselenyl products $(4,5)$ is likely due to the production of electrophilic selenium species, but the observation of 1,2-cis glycoside $\mathbf{5}$ argues against the involvement of a cyclic selenium cation that was previously suggested. ${ }^{23}$ Isolation and characterization of all compounds allowed us to identify a distinct ${ }^{1} \mathrm{H}$ NMR signal for all monosaccharide products $\mathbf{1 - 8}$ and enabled us to assess the reaction selectivity using crude ${ }^{1} \mathrm{H}$ NMR analysis (Figure 2; see the Supporting Information for details).

Initial continuous flow reactions revealed a rather invariable selectivity between desired product 2 and its unwanted isomers 3-5 (ratios 2/3/4/5 greater than 10:1:1:1), as well as high fluctuations of the amounts of bisazido and 1-O-acetyl side products 6-8 (Figure 2A-C; see the Supporting Information for details). Occasionally, reaction outcomes changed drastically as acetyl glycoside $\mathbf{8}$ was produced mainly, as well as an increased amounts of bisazido side products 6-7 and the absence of selenoglycosides 2-3 (Figure 2D). Comparison of ${ }^{1} \mathrm{H}$ NMR spectra of the organic layer before and after solvent evaporation revealed that 6-8 were formed during solvent evaporation rather than during the continuous flow process. Systematic investigations showed that filtration through a bed of silica of the quenched reaction mixture prior to solvent evaporation avoids this reproducibility issue (see Supporting Information). It should be noted that removal of selenide impurities through silica filtration is required for an adequate crystallization of 2 . The use of silica filtration prior to evaporation therefore does not introduce an extra step to the preparative protocol, but simply exchanges the order between silica filtration and solvent evaporation. Presumably, selenoglycosides 2-3 are converted into 6-8 via radical-mediated homolytic cleavage of the $\mathrm{C}-\mathrm{Se}$ anomeric bond or $\beta$ elimination to afford galactal $\mathbf{1}$ as an intermediate. ${ }^{23,27,28}$ Alternatively, oxidation of the phenylselenyl group to the corresponding selenone would afford a good leaving group, rendering $\mathrm{C} 1$ susceptible to nucleophilic attack. ${ }^{29}$ Involvement of $\mathrm{BAIB}$ on the formation of $\mathbf{6 - 8}$ under reduced pressure 

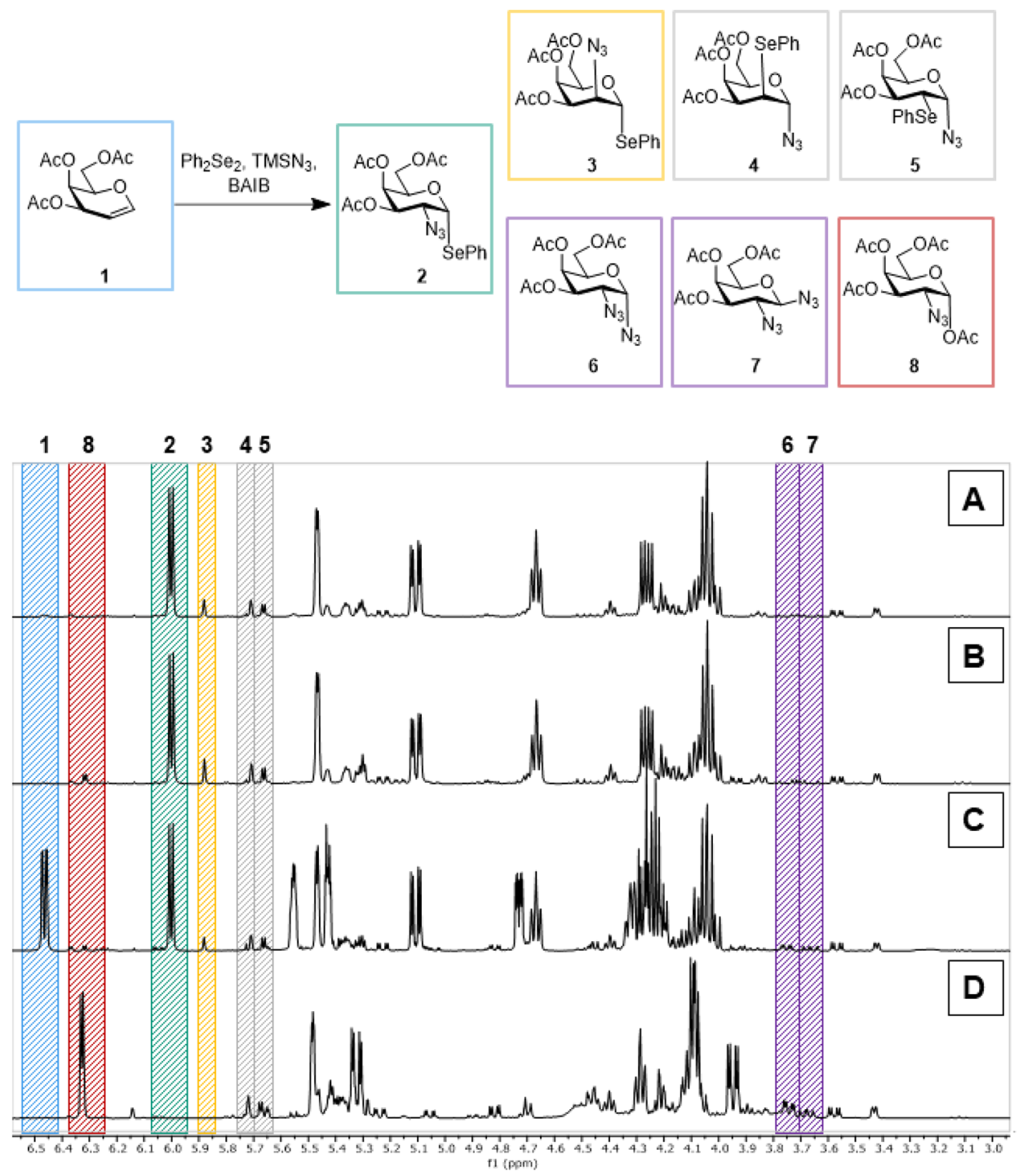

Figure 2. ${ }^{1} \mathrm{H}$ NMR spectroscopic analysis of crude reaction mixtures of the APS reaction of galactal $1 .{ }^{1} \mathrm{H}$ NMR spectra were recorded after solvent evaporation. Highlighted signals correspond to the ${ }^{1} \mathrm{H}$ chemical shifts used to assess the presence of $\mathbf{1 - 8}$ in the reaction crude (see Supporting Information). Representative examples: (A) excellent outcome, only regio- and stereoisomers of 2 (3-5) observed as side products; (B) acceptable outcome, where side products 3-5 and minimum amounts of $\mathbf{8}$ are observed; (C) complex case, with incomplete conversion and products 2-7; (D) extreme case with 8 as main product, absence of glycosyl selenides 2 and 3, and presence of side products 4-7.

Table 1. Screening of Reaction Conditions for the Flow APS Reaction of Galactal 1

\begin{tabular}{|c|c|c|c|c|c|c|c|c|c|c|c|c|c|}
\hline \multirow[b]{2}{*}{ entry } & \multirow[b]{2}{*}{$t_{\mathrm{res} / \min }$} & \multirow[b]{2}{*}{$T\left({ }^{\circ} \mathrm{C}\right)$} & \multirow[b]{2}{*}{$\mathrm{Ph}_{2} \mathrm{Se}_{2}$ (equiv) } & \multirow[b]{2}{*}{$\mathrm{TMSN}_{3}$ (equiv) } & \multirow[b]{2}{*}{ BAIB (equiv) } & \multirow[b]{2}{*}{ Conv $(\%)^{a}$} & \multicolumn{7}{|c|}{ yield $(\%)^{b}$} \\
\hline & & & & & & & 2 & 3 & 4 & 5 & 6 & 7 & 8 \\
\hline 1 & 25 & 27 & 2 & 2 & 1.3 & 100 & 78 & 6 & 8 & 7 & 0 & 0 & 0 \\
\hline 2 & 25 & 27 & 1.3 & 2 & 1.3 & 98 & 74 & 6 & 7 & 7 & 0 & 0 & 0 \\
\hline 3 & 25 & 27 & 1.3 & 1.3 & 2 & 98 & 58 & 5 & 5 & 5 & 0 & 0 & 0 \\
\hline 4 & 25 & 27 & 1.3 & 2 & 1 & 95 & 72 & 6 & 7 & 8 & 0 & 0 & 0 \\
\hline 5 & 25 & 27 & 1.6 & 2 & 1.3 & 100 & 79 & 6 & 7 & 7 & 0 & 0 & $\mathbf{0}$ \\
\hline 6 & 20 & 27 & 1.6 & 2 & 1.3 & 95 & 71 & 6 & 7 & 7 & 0 & 0 & 0 \\
\hline 7 & 25 & 0 & 1.6 & 2 & 1.3 & 62 & 41 & 3 & 4 & 5 & 4 & 3 & 0 \\
\hline 8 & 25 & 40 & 1.6 & 2 & 1.3 & 100 & 65 & 7 & 8 & 8 & 4 & 0 & 0 \\
\hline 9 & 40 & 40 & 1.6 & 2 & 1.3 & 100 & 60 & 7 & 7 & 7 & 4 & 0 & 4 \\
\hline
\end{tabular}

${ }^{a}$ Conversion of galactal (1) determined by ${ }^{1} \mathrm{H}$ NMR using 1,2,4,5-tetramethylbenzene as internal standard. ${ }^{b} \mathrm{NMR}$ yields determined by ${ }^{1} \mathrm{H}$ NMR using 1,2,4,5-tetramethylbenzene as internal standard.

resulting from incomplete reduction in the aqueous quenching was ruled out, as no BAIB signals were observed during ${ }^{1} \mathrm{H}$ NMR analysis.
Once the flow setup with a reliable quenching protocol and a suitable method to assess the reaction outcome was established, reaction conditions were screened aiming to 
maximize the yield of selenoglycoside 2 by achieving full conversion and minimizing side product formation (Table 1 ). Best results were obtained with 1.6 equiv of $\mathrm{Ph}_{2} \mathrm{Se}_{2}, 2$ equiv of $\mathrm{TMSN}_{3}$, and 1.3 equiv of BAIB at room temperature (Table 1 , entry 5) to afford target product 2 in $79 \%$ yield within $25 \mathrm{~min}$. Excess $\mathrm{Ph}_{2} \mathrm{Se}_{2}$ was crucial to minimize the formation of $\mathbf{6 - 8}$ and was necessary for complete substrate consumption (entries 1,2 , and 5). A 2-fold excess of BAIB did not lead to a significant formation of $1-O$-acetyl product 8 , but a low mass balance (full consumption of $\mathbf{1}$, sum of the yields for $\mathbf{2}-\mathbf{5}=$ $73 \%$ ) was obtained (entry 3 ). Lowering the reaction temperature to $0{ }^{\circ} \mathrm{C}$ resulted in a significantly reduced conversion, without any improvement in selectivity toward $\mathbf{2}$ (entry 7$)$. At higher temperatures $\left(40^{\circ} \mathrm{C}\right)$, significantly lower selectivity was observed due to the formation of bisazido side products 6-7 (Table 1, entries 8-9). The selectivity between 2-5 remained roughly unaltered by temperature changes (ratios 2/3/4/5 greater than 10:1:1:1) and did not differ from control experiments in batch (see Supporting Information).

For the large scale production of $\mathbf{2}$, the residence time was extended to $35 \mathrm{~min}$ to guarantee full conversion, and the overall flow rate was increased from 0.24 to $0.34 \mathrm{~mL} / \mathrm{min}$ for enhanced throughput. These conditions were tested at a 1 mmol scale and resulted in a 72\% NMR yield of 2 . Recrystallization yielded $281 \mathrm{mg}$ (61\% yield) of 2 . Only a seventh of the time originally reported in batch is required in flow for the full conversion of $1 \mathrm{mmol}$ of starting material (1). The isolated yield from the flow approach ranks together with the top yields observed in batch (65\%), and well above the average yield of $35 \%$ (see Supporting Information). These results were subsequently reproduced on a gram scale APS reaction ( $5 \mathrm{mmol}$ of 1 ) that resulted in $63 \%(1.46 \mathrm{~g})$ of analytically pure selenogalactoside 2 .

\section{CONCLUSION}

A thorough analysis revealed that the APS reaction is more complex than previously thought, and six different side products can be formed that significantly reduce the yield of the desired selenogalactoside 2. An additional degree of complexity is added when considering that the formation of the target product is reversible. Several factors account for low reproducibility of standard batch APS reactions. The lack of control in the mixing of $\mathrm{TMSN}_{3}$ and BAIB and slow heat transfer processes produce variable results, since elevated local concentrations of azido species can lead either to an increase in bisazido side products $(6-7)$ or to low conversions if azido species are consumed in $\mathrm{N}_{2}$ formation. ${ }^{30}$ Additionally, significant differences in the reaction outcome can result from insufficient quenching, as the desired product is prone to form bisazido and 1-O-acetyl compounds. Performing the reaction in flow allowed for the safe reaction of $\mathrm{TMSN}_{3}$ with BAIB at room temperature, enabling to establish reaction conditions that narrowed the number of side products and reduced the reaction time significantly. Effective and reproducible quenching conditions were key to achieve reproducible, selective reactions. The flow setup allowed for a straightforward scale-up, as the results observed in an analytical scale were steadily reproduced throughout the entire process of a gram-scale synthesis.

\section{EXPERIMENTAL SECTION}

General Methods. Reagents and solvents were obtained from commercial sources, unless stated otherwise. Anhydrous DCM was obtained from a Solvent Dispensing System (J.C. Meyer), and anhydrous chloroform was prepared by adding preactivated molecular sieves ( $4 \AA$, Roth) to HPLC grade chloroform (Merck). Analytical thin layer chromatography (TLC) was performed on glass precoated TLC-plates SIL G/ $\mathrm{UV}_{254}$ sheets (Macherey-Nagel) and visualized with $254 \mathrm{~nm}$ light and sugar stain $(3.70 \mathrm{~mL}$ of $p$-anisaldehyde in $140 \mathrm{~mL}$ of a solution $3.5 \% \mathrm{H}_{2} \mathrm{SO}_{4}$ in ethanol). NMR spectra were obtained using Ascend 400 (Bruker) and Agilent $400 \mathrm{MHz}$ NMR Magnet (Agilent Technologies) spectrometers at 400 $\mathrm{MHz}\left({ }^{1} \mathrm{H}\right)$ and $100 \mathrm{MHz}\left({ }^{13} \mathrm{C}\right) . \mathrm{CDCl}_{3}$ was used as solvent, and chemical shifts $(\delta)$ are reported in ppm relative to the residual solvent peaks $\left(\mathrm{CDCl}_{3}: 7.26 \mathrm{ppm}{ }^{1} \mathrm{H}, 77.16 \mathrm{ppm}{ }^{13} \mathrm{C}\right)$. Assignments were supported by COSY and HSQC experiments. IR spectra were measured with a Spectrum 100 FT-IR Spectrometer (PerkinElmer). Only diagnostic signals are listed. Specific rotations were measured using a UniPol L 1000 polarimeter (Schmidt + Haensch). ESI-HRMS were performed with a Xevo G2-XS Q-Tof (Waters). HPLCs were performed on Agilent 1200 Series systems.

Safety note: Even under continuous flow conditions, extreme caution in the handling of potentially hazardous starting materials and product mixtures is required. The possibility of formation of poisonous and explosive hydrazoic acid must be contemplated at all times.

General Procedure and Equipment for Azidophenylselenylation of Galactal under Continuous Flow Conditions. For screening conditions $(0.49 \mathrm{mmol}$ of $\mathbf{1})$ : The flow setup was assembled using $1.6 \mathrm{~mm}$ O.D. $\times 0.8 \mathrm{~mm}$ I.D. FEP tubing (residence time unit volume: $6 \mathrm{~mL}$ ) and connected by a simple T-mixer ( $0.8 \mathrm{~mm}$ I.D. $)$. The temperature of the residence time unit was regulated at 27 ${ }^{\circ} \mathrm{C}$ using a thermostatic bath unless stated otherwise. 3,4,6-Tri$O$-acetyl- $\alpha$-D-galactal 1 was coevaporated with anhydrous toluene twice and kept under high vacuum for at least 30 min prior to every reaction. Galactal $\mathbf{1}$ was defined as the limiting reagent, and concentrations of other reagents and flow rates were calculated according to desired stoichiometry and residence time. Sample loops were made out of $1.6 \mathrm{~mm}$ O.D. $\times$ $0.8 \mathrm{~mm}$ I.D. FEP (loop A: $3 \mathrm{~mL}$; loop B: $5 \mathrm{~mL}$ ) and were washed and filled with anhydrous DCM prior to reactions. The sample loops were loaded with the following solutions for continuous flow experimentens: Solution A: $0.163 \mathrm{M}$ solution of galactal $1, \mathrm{Ph}_{2} \mathrm{Se}_{2}$, and TMSN $\mathrm{T}_{3}$ in anhydrous DCM. Solution A was loaded in loop A and injected using pump A set to a flow rate $f_{\mathrm{A}}$ (Figure 1), $1.5 \mathrm{~min}$ after injection of solution $\mathrm{B}$ had started. Solution B: BAIB in anhydrous DCM. Solution B was loaded in loop $B$ and then injected using pump $B$ set to a flow rate $f_{\mathrm{B}}=f_{\mathrm{A}}$.

Knauer BlueShadow 40P pumps were used for pumping. A Vapourtec R2 series was used for sample loop command and in-line pressure monitoring. An exchangeable cartridge back pressure regulator (BPR) loaded with a 17-bar cartridge (Upchurch Scientific) was placed downstream, and the reaction mixture was collected and quenched by dropping it into a mixture of DCM $(50 \mathrm{~mL})$ and aq. sat. $\mathrm{NaHCO}_{3}(25$ $\mathrm{mL}), \mathrm{Na}_{2} \mathrm{~S}_{2} \mathrm{O}_{3}(25 \mathrm{~mL})$ that was stirred vigorously. After phase separation, the organic layer was passed through a $6 \mathrm{~cm}$ silica gel plug preloaded on a disposable sample syringe with a filter, 
eluted with additional $50 \mathrm{~mL}$ of DCM (fraction 1, "f1"), and then eluted with $100 \mathrm{~mL}$ of $\mathrm{DCM} /$ Acetone 95:5 (fraction 2, "f2") and $100 \mathrm{~mL}$ of DCM/Acetone 90:10 (fraction 3, "f3"). The solvent of $\mathrm{f} 2$ was evaporated under reduced pressure and was analyzed by ${ }^{1} \mathrm{H}$ NMR to assess reaction outcome, and/or crystallized from isopropanol to obtain target product 2 . Fractions f1 and f3 were kept until the absence of carbohydrates (only required for screening and optimization purposes) was confirmed by thin layer chromatography and/or ${ }^{1} \mathrm{H}$ NMR. Quantifications were performed by ${ }^{1} \mathrm{H}$ NMR of the crude reaction mixture, using 1,2,4,5-tetramethylbenzene as an internal standard (IS). Peak areas of IS $\delta 6.91$ (s, 2H) and of the diagnostic of compounds $\mathbf{1 - 8}$ (see Supporting Information) were used for calculations.

Experimental Data for Monosaccharides 1-8. Galactal 1 was synthesized following previously reported procedures. ${ }^{22}$ Monosaccharides 2-8 were isolated from flow APS reactions. Selenoglycoside 2 was isolated through recrystallization (see below). Fractions enriched in monosaccharides 3-8 were isolated exclusively for characterization purposes. Monosaccharides 2-5 and 6-7 showed similar chromatographic behavior, such that it was not possible to achieve full peak resolution using preparative normal-phase HPLC. The isopropanol filtrate of a $0.49 \mathrm{mmol}$ flow APS synthesis was purified using preparative HPLC purification, from which a fraction enriched in 3 was isolated and repurified through semipreparative HPLC to afford pure selenoglycoside 3 . Monosaccharides 4-8 were isolated from flow APS syntheses on $0.49 \mathrm{mmol}$ scale without filtration through silica prior to evaporation (see Supporting Information). Purification via silica gel chromatography (toluene/acetone $0-10 \%$ as eluent) and subsequent preparative normal-phase HPLC chromatography (hexanes/AcOEt $2-20 \%$ as eluent) allowed isolating fractions enriched in 4-5, 6-7, and 8. For normal-phase (NP) HPLC, YMC-Diol-300-NP columns were used (analytical: 150 $\mathrm{mm} \times 4.60 \mathrm{~mm}$ I.D.; semipreparative: $150 \mathrm{~mm} \times 10.0 \mathrm{~mm}$ I.D.; preparative: $150 \mathrm{~mm} \times 20.0 \mathrm{~mm}$ I.D.), with hexanes/ EtOAc as eluent (flow rates: $1.0,5.0$, and $15.0 \mathrm{~mL} / \mathrm{min}$ for analytical, semipreparative, and preparative chromatography, respectively). The following gradient was used: (1) isocratic $2 \%$ EtOAc in hexanes ( $5 \mathrm{~min}$ ); (2) linear gradient 2 to $20 \%$ EtOAc in hexanes (30 min); (3) linear gradient to $100 \%$ EtOAc (10 min).

3,4,6-Tri-O-acetyl- $\alpha$-D-galactal (1). ${ }^{31}{ }^{1} \mathrm{H}$ NMR (400 MHz, $\left.\mathrm{CDCl}_{3}\right) \delta 6.47(\mathrm{~d}, J=6.1,1 \mathrm{H}, \mathrm{H}-1), 5.56(\mathrm{~s}, 1 \mathrm{H}, \mathrm{H}-3), 5.43(\mathrm{~s}$, $1 \mathrm{H}, \mathrm{H}-4), 4.73$ (d, $J=6.1,1 \mathrm{H}, \mathrm{H}-2), 4.38-4.28(\mathrm{~m}, 1 \mathrm{H})$, 4.28-4.16 (m, 2H), 2.13 (s, 3H), 2.09 (s, 3H), 2.03 (s, 3H). ${ }^{13} \mathrm{C}$ NMR (101 MHz, $\left.\mathrm{CDCl}_{3}\right) \quad \delta 170.7,170.4,170.3$ $\left(\mathrm{OC}(\mathrm{O}) \mathrm{CH}_{3}\right), 145.5$ (C-1), 98.9 (C-2), 72.9 (C-5), 64.0 (C-3), 63.8 (C-4), 62.0 (C-6), 20.98, 20.93, 20.8 (OC(O) $\left.\mathrm{CH}_{3}\right)$.

Phenyl 3,4,6-Tri-O-acetyl-2-azido-2-deoxy-1-seleno- $\alpha$-Dgalactopyranoside (2). ${ }^{12}$ Flow APS syntheses were performed as described above, with stoichiometry and temperature as in Table 1, entry 5 . The following modifications on the reaction setup were performed for the scale-up: The flow reactor was built using $1.6 \mathrm{~mm}$ O.D. $\times 0.8 \mathrm{~mm}$ I.D. FEP tubing (reactor volume: $12 \mathrm{~mL}$ ). Sample loops were built with $3.2 \mathrm{~mm}$ O.D. $\times$ $1.6 \mathrm{~mm}$ I.D. FEP or PFA tubing (Loop A: $6 \mathrm{~mL}$ and Loop B: $10 \mathrm{~mL}$ for $0.98 \mathrm{mmol}$ scale; Loop A: $30 \mathrm{~mL}$ and Loop B: 34 $\mathrm{mL}$ for $4.9 \mathrm{mmol} \mathrm{scale)}$ ). Flow rates were set at $f_{\mathrm{A}}=f_{\mathrm{B}}=0.17$ $\mathrm{mL} / \mathrm{min}$. Loop A was cooled to $0{ }^{\circ} \mathrm{C}$ for $4.9 \mathrm{mmol}$ scale reaction. Recrystallization from isopropanol afforded the product 2 as a white solid $(281 \mathrm{mg}, 0.60 \mathrm{mmol}, 61 \%$ for $0.98 \mathrm{mmol} \mathrm{scale}$; $1.46 \mathrm{~g}, 3.09 \mathrm{mmol}, 63 \%$ for $4.90 \mathrm{mmol} \mathrm{scale})$. IR (film): $2958 \mathrm{~cm}^{-1}$ (w, C-H Ar) $2113 \mathrm{~cm}^{-1}$ (s, N N $\left._{3}\right), 1749$ $\mathrm{cm}^{-1}$ (s, C=O), $1227 \mathrm{~cm}^{-1}$ (s, C-O ester). ${ }^{1} \mathrm{H}$ NMR (400 $\left.\mathrm{MHz} \mathrm{CDCl}_{3}\right) \delta 7.64-7.57(\mathrm{~m}, 3 \mathrm{H}), 7.36-7.27(\mathrm{~m}, 3 \mathrm{H}), 6.00$ (d, $J=5.4 \mathrm{~Hz}, 1 \mathrm{H}, \mathrm{H}-1), 5.47(\mathrm{~d}, J=2.5 \mathrm{~Hz}, 1 \mathrm{H}, \mathrm{H}-4), 5.11$ (dd, $J=10.8,3.2 \mathrm{~Hz}, 1 \mathrm{H}, \mathrm{H}-3), 4.67$ (t, $J=6.4 \mathrm{~Hz}, 1 \mathrm{H}, \mathrm{H}-5$ ), $4.26(\mathrm{dd}, J=10.8,5.4 \mathrm{~Hz}, 1 \mathrm{H}, \mathrm{H}-2)$ ) 4.05 (qd, $J=11.4,6.6 \mathrm{~Hz}$, $\left.2 \mathrm{H}, \mathrm{H}-6,6^{\prime}\right), 2.15\left(\mathrm{~s}, 3 \mathrm{H}, \mathrm{OC}(\mathrm{O}) \mathrm{CH}_{3}\right), 2.07(\mathrm{~s}, 3 \mathrm{H}$, $\left.\mathrm{OC}(\mathrm{O}) \mathrm{CH}_{3}\right), 1.98\left(\mathrm{~s}, 3 \mathrm{H}, \mathrm{OC}(\mathrm{O}) \mathrm{CH}_{3}\right),{ }^{13} \mathrm{C} \mathrm{NMR}(101$ $\left.\mathrm{MHz}, \mathrm{CDCl}_{3}\right) \delta 170.5,170.1,169.7\left(3 \times \mathrm{OC}(\mathrm{O}) \mathrm{CH}_{3}\right), 134.9$, 129.3, 128.3, 127.7, 84.3 (C-1), 71.3 (C-3), 69.1 (C-5), 67.3 (C-4), 61.7 (C-6), 58.9 (C-2), 20.79, 20.77, 20.76 (3 × $\mathrm{OC}(\mathrm{O}) \mathrm{CH}_{3}$ ). HRMS (ESI) calcd for $\mathrm{C}_{18} \mathrm{H}_{21} \mathrm{~N}_{3} \mathrm{O}_{7} \mathrm{SeNa}$, 494.0437; found $[\mathrm{M}+\mathrm{Na}]^{+}, 494.0427$.

Phenyl 3,4,6-Tri-O-acetyl-2-azido-2-deoxy-1-seleno- $\alpha$ - $D$ talopyranoside (3). IR (film) $2950 \mathrm{~cm}^{-1}$ (w, C-H Ar), $2109 \mathrm{~cm}^{-1}\left(\mathrm{~s}, \mathrm{~N}_{3}\right), 1750 \mathrm{~cm}^{-1}(\mathrm{~s}, \mathrm{C}=\mathrm{O}), 1260 \mathrm{~cm}^{-1}(\mathrm{~s}, \mathrm{C}-\mathrm{O}$ ester). ${ }^{1} \mathrm{H}$ NMR $\left(400 \mathrm{MHz}, \mathrm{CDCl}_{3}\right) \delta 7.59$ (dd, $J=7.7,1.8$ $\mathrm{Hz}, 2 \mathrm{H}), 7.35-7.28$ (m, 3H), 5.89 (s, 1H, H-1), 5.45-5.42 $(\mathrm{m}, 1 \mathrm{H}, \mathrm{H}-4), 5.31(\mathrm{t}, J=3.8 \mathrm{~Hz}, 1 \mathrm{H}, \mathrm{H}-3), 4.70$ (ddd, $J=7.3$, 5.7, $1.7 \mathrm{~Hz}, 1 \mathrm{H}, \mathrm{H}-5), 4.23-4.11\left(\mathrm{~m}, 2 \mathrm{H}, \mathrm{H}-6,6^{\prime}\right), 4.08-4.06$ $(\mathrm{m}, 1 \mathrm{H}, \mathrm{H}-2), 2.20\left(\mathrm{~s}, 3 \mathrm{H}, \mathrm{OC}(\mathrm{O}) \mathrm{CH}_{3}\right), 2.10(\mathrm{~s}, 3 \mathrm{H}$, $\left.\mathrm{OC}(\mathrm{O}) \mathrm{CH}_{3}\right), 2.02\left(\mathrm{~s}, 3 \mathrm{H}, \mathrm{OC}(\mathrm{O}) \mathrm{CH}_{3}\right) \cdot{ }^{13} \mathrm{C} \mathrm{NMR}(101$ $\left.\mathrm{MHz}, \mathrm{CDCl}_{3}\right) \delta 170.6\left(\mathrm{OC}(\mathrm{O}) \mathrm{CH}_{3}\right), 170.5\left(\mathrm{OC}(\mathrm{O}) \mathrm{CH}_{3}\right)$, $169.6\left(\mathrm{OC}(\mathrm{O}) \mathrm{CH}_{3}\right), 134.34,129.57,128.63,128.03,83.1(\mathrm{C}-$ $\left.1, J_{C-H}=174 \mathrm{~Hz}\right), 69.7(\mathrm{C}-5), 68.4(\mathrm{C}-3), 65.8(\mathrm{C}-4), 61.9$ (C-6), 59.8 (C-2), 20.8, $20.7\left(3 \times \mathrm{OC}(\mathrm{O}) \mathrm{CH}_{3}\right)$. HRMS (ESI) calcd for $\mathrm{C}_{18} \mathrm{H}_{21} \mathrm{~N}_{3} \mathrm{O}_{7} \mathrm{SeNa}, 494.0437$; found $[\mathrm{M}+\mathrm{Na}]^{+}$, 494.0439 .

3,4,6-Tri-O-acetyl-2-deoxy-2-selenophenyl-1-azido- $\alpha$ - $D$ talopyranoside $(4)^{14}$ and 3,4,6-Tri-O-acetyl-2-deoxy-2selenophenyl-1-azido- $\alpha$-D-galactopyranoside (5). Mixture of glycosides 4 and 5 (1.7:1). IR (film) $2965 \mathrm{~cm}^{-1}$ (w, C-H $\mathrm{Ar}), 2113 \mathrm{~cm}^{-1}\left(\mathrm{~s}, \mathrm{~N}_{3}\right), 1746 \mathrm{~cm}^{-1}(\mathrm{~s}, \mathrm{C}=\mathrm{O}), 1214 \mathrm{~cm}^{-1}(\mathrm{~s}$, $\mathrm{C}-\mathrm{O}$ ester). ${ }^{1} \mathrm{H}$ NMR $\left(400 \mathrm{MHz}, \mathrm{CDCl}_{3}\right) \delta 7.60-7.52(\mathrm{~m}$, $2 \mathrm{H}), 7.35-7.27(\mathrm{~m}, 3 \mathrm{H}), 5.71(\mathrm{~d}, J=1.6 \mathrm{~Hz}, 0.6 \mathrm{H}, \mathbf{H}-\mathbf{1} 4)$, $5.67(\mathrm{~d}, J=4.0 \mathrm{~Hz}, 0.4 \mathrm{H}, \mathrm{H}-1 \mathrm{5}), 5.39-5.35(\mathrm{~m}, 1 \mathrm{H}), 5.33-$ $5.30(\mathrm{~m}, 0.6 \mathrm{H}, \mathrm{C}-\mathrm{H} 4), 5.23(\mathrm{dd}, J=11.8,3.1 \mathrm{~Hz}, 0.4 \mathrm{H}, \mathrm{C}-\mathrm{H}$ 5), $4.40\left(\mathrm{t}_{\mathrm{a}}, J=6.5 \mathrm{~Hz}, 1 \mathrm{H}, \mathrm{H}-54\right.$ and 5), 4.15 (m, 2H, H-6,6' 4 and 5), 3.57 (dd, $J=11.8,4.0 \mathrm{~Hz}, 0.4 \mathrm{H}, \mathrm{H}-25), 3.42$ (ddd, $J$ $=5.1,1.4,0.8 \mathrm{~Hz}, 0.6 \mathrm{H}, \mathrm{H}-24), 2.22\left(\mathrm{~s}, 1.8 \mathrm{H}, \mathrm{C}(\mathrm{O}) \mathrm{CH}_{3} 4\right)$, $2.11\left(\mathrm{~s}, 1.8 \mathrm{H}, \mathrm{C}(\mathrm{O}) \mathrm{CH}_{3} 4\right), 2.10\left(\mathrm{~s}, 1.2 \mathrm{H}, \mathrm{C}(\mathrm{O}) \mathrm{CH}_{3} 5\right), 2.07$ (s, 1.8H, C(O) $\left.\mathrm{CH}_{3} 4\right), 2.06\left(\mathrm{~s}, \mathrm{C}(\mathrm{O}) \mathrm{CH}_{3} .1 .2 \mathrm{H}, 5\right), 1.89$ (s, $\left.1.2 \mathrm{H}, \mathrm{C}(\mathrm{O}) \mathrm{CH}_{3} 5\right) .{ }^{13} \mathrm{C} \mathrm{NMR}\left(101 \mathrm{MHz}, \mathrm{CDCl}_{3}\right) \delta 170.70$ $\left(\mathrm{C}(\mathrm{O}) \mathrm{CH}_{3}\right), 170.66\left(\mathrm{C}(\mathrm{O}) \mathrm{CH}_{3}\right), 170.1\left(\mathrm{C}(\mathrm{O}) \mathrm{CH}_{3}\right), 170.00$ $\left(\mathrm{C}(\mathrm{O}) \mathrm{CH}_{3}\right), 169.98\left(\mathrm{C}(\mathrm{O}) \mathrm{CH}_{3}\right), 169.8\left(\mathrm{C}(\mathrm{O}) \mathrm{CH}_{3}\right), 134.5$, 134.4, 130.3, 129.7, 129.4, 128.9, 128.5, 128.2, 91.6 (C-1 4, $\left.J_{\mathrm{C}-\mathrm{H}}=177 \mathrm{~Hz}\right), 90.9\left(\mathbf{C}-15, J_{\mathrm{C}-\mathrm{H}}=173 \mathrm{~Hz}\right), 69.8,69.3,69.0$, 67.6, 66.7, 66.2, 62.0, 61.9, 46.0 (C-2 4), 43.4 (C-2 5), 21.07 $\left(\mathrm{C}(\mathrm{O}) \mathrm{CH}_{3}\right), 21.03\left(\mathrm{C}(\mathrm{O}) \mathrm{CH}_{3}\right), 20.86\left(2 \times \mathrm{C}(\mathrm{O}) \mathrm{CH}_{3}\right), 20.81$ $\left(\mathrm{C}(\mathrm{O}) \mathrm{CH}_{3}\right), 20.7\left(\mathrm{C}(\mathrm{O}) \mathrm{CH}_{3}\right)$. HRMS (ESI) calcd for $\mathrm{C}_{18} \mathrm{H}_{21} \mathrm{~N}_{3} \mathrm{O}_{7} \mathrm{SeNa}$, 494.0437; found $[\mathrm{M}+\mathrm{Na}]^{+}$, 494.0438.

3,4,6-Tri-O-acetyl-2-azido-2-deoxy-1-azido- $\alpha, \beta$-D-galactopyranoside $(6,7) .^{32}$ Mixture of glycosides 6 and 7 (7:1). IR (film) $2113 \mathrm{~cm}^{-1}\left(\mathrm{~s}, \mathrm{~N}_{3}\right), 1745 \mathrm{~cm}^{-1}(\mathrm{~s}, \mathrm{C}=\mathrm{O}), 1224 \mathrm{~cm}^{-1}(\mathrm{~s}$, $\mathrm{C}-\mathrm{O}$ ester). ${ }^{1} \mathrm{H}$ NMR (400 MHz, $\left.\mathrm{CDCl}_{3}\right) \delta 5.46(\mathrm{dd}, J=3.3$, $1.4 \mathrm{~Hz}, 0.87 \mathrm{H}, \mathrm{H}-4$ 6), 5.43 (d, J=3.4 Hz, 0.87H, H-1 6), 5.40 $(\mathrm{dd}, J=11.0,3.2 \mathrm{~Hz}, 0.87 \mathrm{H}, \mathrm{H}-3 \mathrm{6}), 5.35(\mathrm{~d}, J=3.3 \mathrm{~Hz}$, $0.13 \mathrm{H}, \mathrm{H}-4 \mathrm{7}), 4.82(\mathrm{dd}, J=10.9,3.3 \mathrm{~Hz}, 0.13 \mathrm{H}, \mathrm{H}-3$ 7), 4.71 (d, $J=7.9 \mathrm{~Hz}, 0.13 \mathrm{H}, \mathrm{H}-1$ 7), $4.46(\mathrm{t}, J=7.0 \mathrm{~Hz}, 0.87 \mathrm{H}, \mathrm{H}-5$ 6), 4.16-4.03 (m, 2H, H-6,6' 6, 7), $3.91(\mathrm{td}, J=6.6,1.2 \mathrm{~Hz}$, $0.13 \mathrm{H}, \mathrm{H}-5$ 7), 3.76 (dd, $J=11.0,3.4 \mathrm{~Hz}, 0.87 \mathrm{H}, \mathrm{H}-2$ 6), 3.67 
$(\mathrm{dd}, J=10.9,8.0 \mathrm{~Hz}, 0.13 \mathrm{H}, \mathrm{H}-2 \mathrm{7}), 2.16(\mathrm{~s}, 0.39 \mathrm{H}$, $\left.\mathrm{OC}(\mathrm{O}) \mathrm{CH}_{3} 7\right), 2.15\left(\mathrm{~s}, 2.61 \mathrm{H}, \mathrm{OC}(\mathrm{O}) \mathrm{CH}_{3} 6\right), 2.06(\mathrm{~m}, 6 \mathrm{H}, 2$ $\left.\times \mathrm{OC}(\mathrm{O}) \mathrm{CH}_{3} 6,7\right) \cdot{ }^{13} \mathrm{C} \mathrm{NMR}\left(101 \mathrm{MHz}, \mathrm{CDCl}_{3}\right) \delta 170.72$ $\left(\mathrm{C}(\mathrm{O}) \mathrm{CH}_{3}\right), 170.68\left(\mathrm{C}(\mathrm{O}) \mathrm{CH}_{3}\right), 170.3\left(\mathrm{C}(\mathrm{O}) \mathrm{CH}_{3}\right), 170.1$ $\left(\mathrm{C}(\mathrm{O}) \mathrm{CH}_{3}\right), 96.6\left(\mathbf{C}-1\right.$ 7, $\left.J_{\mathrm{C}-\mathrm{H}}=165 \mathrm{~Hz}\right), 92.5\left(\mathbf{C}-1\right.$ 6, $J_{\mathrm{C}-\mathrm{H}}=$ $176 \mathrm{~Hz}$ ), 71.3 (C-3 7), 71.1 (C-5 7), 68.5 (C-3 6), 67.8 (C-4 6), 66.8 (C-5 6), 66.5 (C-4 7), 62.1 (C-6 7), 61.9 (C-6 6), $61.7(\mathrm{C}-27), 58.1(\mathrm{C}-26), 20.89\left(\mathrm{C}(\mathrm{O}) \mathrm{CH}_{3}\right), 20.87(\mathrm{C}(\mathrm{O})$ $\left.\mathrm{CH}_{3}\right), 20.84\left(\mathrm{C}(\mathrm{O}) \mathrm{CH}_{3}\right), 20.81\left(\mathrm{C}(\mathrm{O}) \mathrm{CH}_{3}\right), 20.79(\mathrm{C}(\mathrm{O})$ $\left.\mathrm{CH}_{3}\right), 20.78\left(\mathrm{C}(\mathrm{O}) \mathrm{CH}_{3}\right)$.

$1,3,4,6$-Tetra-O-acetyl-2-azido-2-deoxy- $\alpha$-D-galactopyranoside (8). $[\alpha]_{\mathrm{D}}{ }^{25}\left(c 1.00, \mathrm{CHCl}_{3}\right)+85.9$. IR (film) 2116 $\mathrm{cm}^{-1}\left(\mathrm{~s}, \mathrm{~N}_{3}\right), 1751 \mathrm{~cm}^{-1}(\mathrm{~s}, \mathrm{C}=\mathrm{O}), 1215 \mathrm{~cm}^{-1}(\mathrm{~s}, \mathrm{C}-\mathrm{O}$ ester). ${ }^{1} \mathrm{H}$ NMR $\left(400 \mathrm{MHz}, \mathrm{CDCl}_{3}\right) \delta 6.32(\mathrm{~d}, J=3.6 \mathrm{~Hz}, 1 \mathrm{H}$, H-1), 5.49-5.46 (m, 1H, H-4), 5.31 (dd, $J=11.0,3.2 \mathrm{~Hz}, 1 \mathrm{H}$, $\mathrm{H}-3), 4.27(\mathrm{t}, J=6.8 \mathrm{~Hz}, 1 \mathrm{H}, \mathrm{H}-5), 4.08(\mathrm{dd}, J=6.7,3.4 \mathrm{~Hz}$, $\left.2 \mathrm{H}, \mathrm{H}-6,6^{\prime}\right), 3.94$ (dd, $\left.J=11.0,3.6 \mathrm{~Hz}, 1 \mathrm{H}, \mathrm{H}-2\right), 2.17$ (s, 3H, $\left.\mathrm{C}(\mathrm{O}) \mathrm{CH}_{3}\right), 2.17\left(\mathrm{~s}, 3 \mathrm{H}, \mathrm{C}(\mathrm{O}) \mathrm{CH}_{3}\right), 2.07\left(\mathrm{~s}, 3 \mathrm{H}, \mathrm{C}(\mathrm{O}) \mathrm{CH}_{3}\right)$, $2.03\left(\mathrm{~s}, 3 \mathrm{H}, \mathrm{C}(\mathrm{O}) \mathrm{CH}_{3}\right) .{ }^{13} \mathrm{C} \mathrm{NMR}\left(101 \mathrm{MHz}, \mathrm{CDCl}_{3}\right) \delta$ $170.5\left(\mathrm{C}(\mathrm{O}) \mathrm{CH}_{3}\right), 170.2\left(\mathrm{C}(\mathrm{O}) \mathrm{CH}_{3}\right), 170.0\left(\mathrm{C}(\mathrm{O}) \mathrm{CH}_{3}\right)$, $168.9\left(\mathrm{C}(\mathrm{O}) \mathrm{CH}_{3}\right), 90.5\left(\mathrm{C}-1, J_{\mathrm{C}-\mathrm{H}}=180 \mathrm{~Hz}\right), 68.9(\mathrm{C}-3)$, 68.8 (C-5), 66.9 (C-4), 61.2 (C-6), 56.9 (C-2), 21.1 (C(O) $\left.\mathrm{CH}_{3}\right), 20.81\left(2 \times \mathrm{C}(\mathrm{O}) \mathrm{CH}_{3}\right), 20.78\left(\mathrm{C}(\mathrm{O}) \mathrm{CH}_{3}\right) . \mathrm{HRMS}$ (ESI) calcd for $\mathrm{C}_{14} \mathrm{H}_{19} \mathrm{~N}_{3} \mathrm{O}_{9} \mathrm{Na}, 396.1014$; found $[\mathrm{M}+\mathrm{Na}]^{+}$, 396.1021.

\section{ASSOCIATED CONTENT}

\section{S Supporting Information}

The Supporting Information is available free of charge at https://pubs.acs.org/doi/10.1021/acs.oprd.9b00456.

Additional experimental data and ${ }^{1} \mathrm{H},{ }^{13} \mathrm{C}$, COSY, and HSQC NMR spectra of compounds 2-8 (PDF)

\section{AUTHOR INFORMATION}

\section{Corresponding Author}

*E-mail: peter.seeberger@mpikg.mpg.de.

\section{ORCID $\odot$}

Bartholomäus Pieber: 0000-0001-8689-388X

Peter H. Seeberger: 0000-0003-3394-8466

Notes

The authors declare no competing financial interest.

\section{ACKNOWLEDGMENTS}

We gratefully acknowledge the Max-Planck Society for generous financial support. We acknowledge DFG SFB/ Transregio 67 for funding to M.G. B.P. acknowledges financial support by a Liebig Fellowship of the German Chemical Industry Fund (Fonds der Chemischen Industrie, FCI). We are grateful to Dr. Anna Nickel (nee Chentsova) for initial advice in flow technology to M.G. We thank Eva Settels for support with HPLCs and other analytical devices and Olaf Niemeyer for support with NMR studies.

\section{ABBREVIATIONS}

APS, azidophenylselenylation; BAIB, bisacetoxy iodobenzene; GalN, galactosamine; GalNAc, $N$-acetylgalactosamine; GlcN, glucosamine; TLC, thin layer chromatography

\section{REFERENCES}

(1) Essentials of Glycobiology, 2nd ed.; Varki, A., Cummings, R. D., Esko, J. D., Freeze, H. H., Stanley, P., Bertozzi, C. R., Hart, G. W.,
Etzler, M. E., Eds.; Cold Spring Harbor Laboratory Press: Cold Spring Harbor, 2009.

(2) Knirel, Y. A. O-Specific Polysaccharides of Gram-Negative Bacteria. In Microbial Glycobiology; Moran, A. P., Ed.; Elsevier: 2010; pp 57-73.

(3) Wang, S. K.; Cheng, C. M. Glycan-Based Diagnostic Devices: Current Progress, Challenges and Perspectives. Chem. Commun. 2015, 51, 16750-16762.

(4) Wilson, R. M.; Danishefsky, S. J. A Vision for Vaccines Built from Fully Synthetic Tumor-Associated Antigens: From the Laboratory to the Clinic. J. Am. Chem. Soc. 2013, 135, 14462-14472.

(5) Ernst, B.; Magnani, J. L. From Carbohydrate Leads to Glycomimetic Drugs. Nat. Rev. Drug Discovery 2009, 8, 661-677.

(6) Werz, D. B.; Ranzinger, R.; Herget, S.; Adibekian, A.; Von der Lieth, C. W.; Seeberger, P. H. Exploring the Structural Diversity of Mammalian Carbohydrates ("glycospace") by Statistical Databank Analysis. ACS Chem. Biol. 2007, 2, 685-691.

(7) Winterfeld, G. a.; Schmidt, R. R. Nitroglycal Concatenation: A Broadly Applicable and Efficient Approach to the Synthesis of Complex O-Glycans. Angew. Chem., Int. Ed. 2001, 40, 2654-2657.

(8) Leblanc, Y.; Fitzsimmons, B. J.; Springer, J. P.; Rokach, J. [4 + 2] Cycloaddition Reaction of Dibenzyl Azodicarboxylate and Glycals. J. Am. Chem. Soc. 1989, 111, 2995-3000.

(9) Du Bois, J. Du; Tomooka, C. S.; Hong, J.; Carreira, E. M. Novel, Stereoselective Synthesis of 2-Amino Saccharides. J. Am. Chem. Soc. 1997, 119, 3179-3180.

(10) Danishefsky, S. J.; Koseki, K.; Griffith, D. A.; Gervay, J.; Peterson, J. M.; McDonald, F. E.; Oriyama, T. Azaglycosylation of Complex Stannyl Alkoxides with Glycal-Derived Iodo Sulfonamides: A Straightforward Synthesis of Sialyl-Lewis X Antigen and Other Oligosaccharide Domains. J. Am. Chem. Soc. 1992, 114, 8331-8333.

(11) Lemieux, R. U.; Ratcliffe, R. M. The Azidonitration of Tri-OAcetyl-D-Galactal. Can. J. Chem. 1979, 57, 1244-1251.

(12) Santoyo-Gonzalez, F.; Calvo-Flores, F. G.; Garcia-Mendoza, P.; Hernandez-Mateo, F.; Isac-Garcia, J.; Robles-Diaz, R. Synthesis of Phenyl 2-Azido-2-Deoxy-1-Selenoglicosides from Glycals. J. Org. Chem. 1993, 58, 6122-6125.

(13) (a) Emmadi, M.; Kulkarni, S. S. Rapid Transformation of DMannose into Orthogonally Protected D-Glucosamine and DGalactosamine Thioglycosides. J. Org. Chem. 2011, 76, 4703-4709. (b) Emmadi, M.; Kulkarni, S. S. Orthogonally Protected DGalactosamine Thioglycoside Building Blocks via Highly Regioselective, Double Serial and Double Parallel Inversions of $\beta$-DThiomannoside. Org. Biomol. Chem. 2013, 11, 4825-4830. (c) Emmadi, M.; Kulkarni, S. S. Synthesis of Orthogonally Protected Bacterial, Rare-Sugar and D-Glycosamine Building Blocks. Nat. Protoc. 2013, 8, 1870-1889.

(14) Mironov, Y. V.; Sherman, A. A.; Nifantiev, N. E. Homogeneous Azidophenylselenylation of Glycals Using $\mathrm{TMSN}_{3}-\mathrm{Ph}_{2} \mathrm{Se}_{2}-\mathrm{PhI}-$ (OAc) ${ }_{2}$. Tetrahedron Lett. 2004, 45, 9107-9110.

(15) Mironov, Y. V.; Sherman, A. A.; Nifantiev, N. E. Homogeneous Azidophenylselenylation of Glucals. Mendeleev Commun. 2008, 18, 241-243.

(16) Czernecki, S.; Ayadi, E.; Randriamandimby, D. Seleno Glycosides. 3. Synthesis of Phenyl 2-(N-Acetylamino)-and 2-Azido2-Deoxy-1-Seleno- $\alpha$-D-Glycopyranosides via Azido-Phenylselenylation of Diversely Protected Glycals. J. Org. Chem. 1994, 59, 82568260.

(17) Czernecki, S.; Randriamandimby, D. Azido-Phenylselenylation of Protected Glycals. Tetrahedron Lett. 1993, 34, 7915-7916.

(18) Langerman, N. Chemical Safety: Explosion hazard in synthesis of azidotrimethylsilane http://cen.acs.org/articles/92/i43/ChemicalSafety-Explosion-hazard-synthesis.html (accessed Oct 10, 2019).

(19) Baxendale, I. R. The Integration of Flow Reactors into Synthetic Organic Chemistry. J. Chem. Technol. Biotechnol. 2013, 88, 519-552.

(20) Gutmann, B.; Cantillo, D.; Kappe, C. O. Continuous-Flow Technology - A Tool for the Safe Manufacturing of Active 
Pharmaceutical Ingredients. Angew. Chem., Int. Ed. 2015, 54, 66886728.

(21) Plutschack, M. B.; Pieber, B.; Gilmore, K.; Seeberger, P. H. The Hitchhiker's Guide to Flow Chemistry. Chem. Rev. 2017, 117, 11796-11893.

(22) Eller, S.; Collot, M.; Yin, J.; Hahm, H. S.; Seeberger, P. H. Automated Solid-Phase Synthesis of Chondroitin Sulfate Glycosaminoglycans. Angew. Chem., Int. Ed. 2013, 52, 5858-5861.

(23) Mironov, Y. V.; Grachev, A. A.; Lalov, A. V.; Sherman, A. A.; Egorov, M. P.; Nifantiev, N. E. A Study of the Mechanism of the Azidophenylselenylation of Glycals. Russ. Chem. Bull. 2009, 58, 284290.

(24) Chloroform was used as carrier solvent for improving the performance of the pump.

(25) Nowacki, A.; Liberek, B. Comparative Conformational Studies of 3,4,6-Tri-O-Acetyl-1,5-Anhydro-2-Deoxyhex-1-Enitols at the DFT Level. Carbohydr. Res. 2018, 462, 13-27.

(26) Tingoli, M.; Tiecco, M.; Testaferri, L.; Temperini, A. Iodosobenzene Diacetate and Diphenyl Diselenide: An Electrophilic Selenenylating Agent of Double Bonds. Synth. Commun. 1998, 28, $1769-1778$.

(27) Santoyo-González, F.; Calvo-Flores, F. G.; Hernández-Mateo, F.; García-Mendoza, P.; Isac-García, J.; Pérez-Alvarez, M. D. Radical $\beta$-Elimination of Vicinal Phenylselenide and Xanthate Azides in Sugar Derivatives. Synlett 1994, 1994, 454-456.

(28) SanMartin, R.; Tavassoli, B.; Walsh, K. E.; Walter, D. S.; Gallagher, T. Radical-Mediated Synthesis of $\alpha$-C-Glycosides Based on N-Acyl Galactosamine. Org. Lett. 2000, 2, 4051-4054.

(29) Tiecco, M.; Tingoli, M.; Testaferri, L. The Use of Selenium Containing Intermediates to Mediate or Catalyze New Organic Reactions. Pure Appl. Chem. 1993, 65, 715-722.

(30) Pedersen, C. M.; Marinescu, L. G.; Bols, M. Radical Substitution with Azide: $\mathrm{TMSN}_{3}-\mathrm{PhI}(\mathrm{OAc})_{2}$ as a Substitute of $\mathrm{IN}_{3}$. Org. Biomol. Chem. 2005, 3, 816-822.

(31) Shiao, T. C.; Rodrigue, J.; Renaudet, O.; Roy, R. Synthesis of 3,4,6-Tri-O-Acetyl-D-Galactal. In Carbohydrate Chemistry: Proven Synthetic Methods, Vol. 2; van der Marel, G. A., Codée, J. D. C., Eds.; CRC Press: Boca Raton, 2014; pp 253-256.

(32) Snider, B. B.; Lin, H. An Improved Procedure for the Conversion of Alkenes and Glycals to 1,2-Diazides Using $\mathrm{Mn}(\mathrm{OAc})_{3}$. $2 \mathrm{H}_{2} \mathrm{O}$ in Acetonitrile Containing Trifluoroacetic Acid. Synth. Commun. 1998, 28, 1913-1922. 